\title{
Transformational Leadership dalam Menurunkan Beban Kerja Perawat Puskesmas
}

\author{
Nur Wahyu Puspitasari ${ }^{1}$, Luky Dwiantoro ${ }^{2}$ \\ ${ }^{1,2}$ Program Studi Magister Keperawatan Universitas Diponegoro \\ Jln Prof. H. Soedarto, S.H. Tembalang Semarang Kotak Pos 1269 Telepon (024) 7460020 \\ Email: nurwahyup@yahoo.co.id ${ }^{1}$
}

\begin{abstract}
Abstrak
Puskesmas merupakan ujung tombak penyelenggaraan usaha kesehatan masyarakat maupun usaha perseorangan di strata pertama pelayanan kesehatan yang bergerak dalam bidang promotif, preventif dan kuratif yang bertujuan mencapai derajat kesehatan optimal. Dalam menjalankan upaya pencapaian derajat kesehatan yang optimal, seringkali perawat mengalami stres sehingga menyebabkan pelayanan di puskesmas ataupun pelaksanaan program perawatan kesehatan masyarakat tidak berjalan optimal. Salah satunya disebabkan oleh beban kerja yang cukup tinggi karena jumlah tenaga kesehatan yang tidak sebanding dengan jumlah tenaga kesehatan, maupun karena pola kepemimpinan yang tidak memperhatikan keinginan bawahan maupun atau kepemimpinan transaksional. Mengingat kerja manusia bersifat fisik dan mental, maka masing-masing mempunyai tingkat pembebanan yang berbeda-beda. Diperlukan perubahan pola kepemimpinan agar beban kerja dapat diturunkan dan program perawatan kesehatan masyarakat dan asuhan keperawatan di pelayanan rawat inap puskesmas dapat berjalan optimal. Tujuan : Memberikan gambaran upaya menurunkan beban kerja perawat puskesmas melalui kepemimpinan transformasional. Metode: Literature review dengan mencari beberapa artikel jurnal penelitian yang dipublikasikan melalui data base eletronik. Data base eletronik yang digunakan: PubMed, EBSCO dan Cochrane Library. Dengan menggunakan kata kunci: Transformational Leadership, Beban kerja, Perawat puskesmas. Serta menggunakan referensi handbook nursing. Hasil : Beban kerja dapat diturunkan dengan penerapan transformasional leadership. Diskusi: Untuk mewujudkan optimalisasi pelayanan pratama dan mengoptimalkan kegiatan perawatan kesehatan masyarakat salah satu hal yang diperlukan adalah perubahan penerapan pola kepemimpinan dari kepemimpinan transaksional menuju kepemimpinan transformasional.
\end{abstract}

Kata kunci $\quad$ : Transformational Leadership, Beban kerja, Perawat Puskesmas

\begin{abstract}
Abstrack
Community health center is the spearhead of the implementation of public health business as well as individual business in the first strata of health services that is engaged in promotive, preventive and curative activities aimed at achieving optimum health status. In carrying out efforts to achieve the optimal health degree, often nurses experience stress, causing services in health centers or the implementation of public health care programs are not running optimally. One of them is caused by the high work load because the number of health workers is not proportional to the number of health workers, nor because of the leadership pattern that does not pay attention to the desires of subordinates or transactional leadership. Considering that human labor is both physical and mental, each has different levels of loading. Changes in leadership patterns are needed so that the workload can be lowered and the community health care program and nursing care in the inpatient service of puskesmas can run optimally. Objective: Provides an overview of efforts to reduce the workload of nurses of puskesmas through transformational leadership.Method: Literature review by searching for several research journal articles published via electronic data base. Electronic data base used: PubMed, EBSCO and Cochrane Library. By using the keywords: Transformational Leadership, Workload, Community Health Nurse. As well as using nursing handbook reference. Result: Workload can be lowered by application of transformational leadership. Discussion: In order to realize primary services and optimize public health care activities it is necessary to change the application of leadership patterns from transactional leadership to transformational leadership.
\end{abstract}

Keywords $\quad$ : Transformational Leadership, Workload, Community Health Nurse 


\section{Pendahuluan}

Pembangunan kesehatan bertujuan meningkatkan kesadaran, kemauan dan kemampuan hidup sehat bagi setiap orang agar terwujud derajat kesehatan yang optimal. Agar tujuan tersebut tercapai perlu upaya dari seluruh potensi bangsa mulai dari masyarakat, swasta sampai pemerintah pusat dan daerah. Salah satu upaya peningkatan kesehatan dilakukan oleh pemerintah daerah melalui puskesmas.

Puskesmas sebagai sarana pelayanan kesehatanstrata pertama dalam pemberian pelayanan kesehatankepada masyarakat mempunyai peranan penting dalammewujudkan derajat kesehatan masyarakat ${ }^{1}$.Puskesmas merupakan ujung tombak penyelenggaraan usaha kesehatan masyarakat maupun usaha kesehatan perseorangan di strata pertama pelayanan kesehatan yang bergerak dalam bidang promotif, preventif, dan kuratif dan bertujuan mencapai derajat kesehatan yang optimal.

Perawatan kesehatan masyarakat merupakan salah satu unsur keperawatan yang berfokus pada kegiatan asuhan keperawatan di masyarakat yang mampu membawa peningkatan kesehatan menuju sehat optimal. Kegiatan perawatan kesehatan masyarakat berfokus pada upaya promotif, preventif dan kuratif. Terlaksananya kegiatan promotif dan preventif yang dilaksanakan di puskesmas akan menurunkan angka kesakitan dan meningkatkan derajat kesehatan.

Upaya keperawatan kesehatan masyarakat adalah pelayanan profesional yang terintegrasi dengan pelayanan kesehatan di puskesmas yang dilaksanakan oleh perawat. Perawat Puskesmas mempunyai tugas pokok memberikan pelayanan keperawatan dalam bentuk asuhan keperawatan individu, keluarga, kelompok dan masyarakat. Untuk mencapai kemandirian masyarakat baik di sarana pelayanan kesehatan seperti rumah sakit dan puskesmas.

Dalam pelaksanaan program puskesmas, perawat merupakan salah satu tenaga kesehatan yang selama ini banyak memegang tanggung jawab pelaksanaan program perawatan kesehatan masyarakat, mulai pelayanan di dalam gedung seperti pelayanan rawat inap, rawat jalan, serta pemegang beberapa program yang menuntut kerja di lapangan seperti pendidikan kesehatan kepada masyarakat, kunjungan rumah, ditambah tugas- tugas administrasi tambahan misalnya bendahara.

Beban kerja merupakan sesuatu yang muncul dari interaksi antara tuntutan tugas, lingkungan kerja dimana digunakan sebagai tempat kerja. Mengingat kerja manusia bersifat fisik dan mental, maka masing-masing mempunyai tingkat pembebanan yang berbedabeda. ${ }^{2}$ Pada tenaga keperawatan, beban kerja dipengaruhi oleh fungsinya untuk melaksanakan asuhan keperawatan serta kapasitasnya untuk melakukan fungsi tersebut. Beban kerja seorang perawat dapat dihitung dari waktu efektif yang digunakan untuk menyelesaikan tugas-tugas yang menjadi bebannya. ${ }^{3}$ Sehingga dalam kapasitasnya sebagai perawat yang melaksanakan tugas dan fungsi asuhan keperawatan serta waktu yang telah digunakan.

Pelayanan keperawatan saat ini semakin kompleks dan dihadapkan dengan berbagai tantangan, antara lain peningkatan beban kerja dan peningkatan biaya kesehatan, sebagai salah satu profesi dengan jumlah terbesar, perawat sering menjadi sorotan, sehingga pemimpin keperawatan harus terus memperbaiki pendekatan dan gaya kepemimpinan agar lebih efektif. ${ }^{4}$

Beberapa perawat sempat mengeluhkan tingginya beban kerja seperti ini. Menurut hasil survey dari PPNI tahun 2008, sekitar 50,9\% perawat yang bekerja di empat propinsi di Indonesia mengalami stress kerja, sering pusing, lelah, tidak bisa beristirahat karena beban kerja terlalu tinggi dan menyita waktu, gaji rendah tanpa insentif memadai. ${ }^{2}$

Beban kerja berkaitan erat dengan produktifitas tenaga kesehatan, dimana 53,2\% waktu yang benar-benar produktif yang digunakan pelayanan kesehatan langsung dan sisanya 39,9\% digunakan untuk kegiatan penunjang. ${ }^{5}$ Beban kerja yang terlalu berat atau kemampuan fisik yang terlalu lemah dapat mengakibatkan seorang perawat menderita gangguan atau penyakit akibat kerja, atau tidak optimal dalam kegiatan perawatan kesehatan 
masyarakat. ${ }^{5}$ International Council of Nurses (ICN) menunjukkan, peningkatan beban kerja perawat dari empat pasien jadi enam orang telah mengakibatkan $14 \%$ peningkatkan kematian pasien yang dirawat dalam 30 hari pertama sejak dirawat di Puskesmas. ${ }^{6}$ Beban kerja yang tinggi yang disebabkan tidak terpenuhinya kebutuhan perawat juga terlihat pada rendahnya capaian SPM program DKK Rembang dimana perawat banyak terlibat seperti CDR TBC, hanya $66,4 \%$ dibawah target nasional $70 \%$ dan sasaran Perkesmas $4910 \mathrm{KK}$ hanya terealisasi $6,68 \%$. $^{3}$

Akibat negatif dari meningkatnya beban kerja adalah kemungkinan timbul emosi perawat yang tidak sesuai yang diharapkan pasien. Beban kerja yang berlebihan ini sangat berpengaruh terhadap produktifitas tenaga kesehatan dan tentu saja berpengaruh terhadap produktifitas perawat. $^{7}$ Aspek mental dalam perhitungan beban kerja memperhatikan kondisi mental atau psikologis dan lebih menekankan pada hubungan interpersonal antara perawat dengan kepala ruang, perawat dengan perawat lainnya dan hubungan perawat dengan pasien, yang dapat mempengaruhi keserasian dan produktifitas kerja bagi perawat sebagai alokasi penggunaan waktu guna peningkatan pelayanan keperawatan terhadap pasien. ${ }^{8}$

Beban kerja secara umum terdiri dari beban kerja fisik dan mental. ${ }^{9}$ Beban kerja fisik merupakan beban kerja yang terjadi akibat kerja yang melibatkan tubuh secara fisik. Beban kerja mental merupakan beban kerja yang terjadi akibat tekanan psikologis.

Beban kerja fisik merupakan tugas yang sehari-hari dilakukan oleh perawat, mulai dari pelaksanaan asuhan keperawatan kepada klien individu misalnya pengkajian, memasang infus, perawatan luka, injeksi, memberikan obat pada pasien, memberikan pendidikan kesehatan pada pasien, mengangkat pasien, memandikan pasien, membantu pasien ke kamar mandi, mendorong peralatan kesehatan, merapikan tempat tidur pasien, mendorong brankart pasien, pencatatan dokumentasi asuhan keperawatan dan lain-lain.

Beban kerja fisik dalam kegiatan perawatan kesehatan masyarakat masyarakat diantaranya pelaksanaan kegiatan asuhan keperawatan di dalam gedung yakni pelayanan konsultasi penyakit IMS, penyuluhan individu untuk pencegahan penyakit menular dan diluar gedung misalnya imunisasi, kunjungan rumah, pengkajian kesehatan keluarga, penyuluhan kesehatan pada keluarga dan pelaksanaan kegiatan yang merupakan program puskesmas misalnya pendidikan kesehatan kepada masyatrakat tentang DBD, Tb Paru, HIV Aids, Kusta, Imunisasi, Diare, Malaria, Rabies, Filariasis. Kegiatan pemberdayaan masyarakat mulai dari pembinaan dan pemberdayaan kader, kunjungan kontak serumah pada penderita $\mathrm{Tb}$, pembinaan UKS, survei untuk penelusuran pan pencegahan penularan penyakit, dan lain-lain. Beban kerja tambahan misalnya kepengurusan dalam organisasi di institusi kerja, menjadi bendahara, sampai membantu administrasi pencatatan dan pelaporan.

Beban kerja karena mental disebabkan oleh situasi kerja, tekanan atasan, target capaian dan waktu dalam pelaksanaan program, ketidakmampuan memanage waktu maupun pengaruh lingkungan. ${ }^{10}$ Misalnya tekanan dari atasan yang bersifat otoriter, target pencapaian yang terlalu tinggi dan tidak diimbangi dengan kemampuan, persaingan kerja yang tidak sehat, tidak adanya dukungan dari atasan saat melakukan suatu pekerjaan, rekan kerja yang sulit diajak bekerja sama, tim yang tidak berjalan dengan baik, pandangan miring orang lain terhadap hasil kerja, bekerja shift atau bergiliran, mempersiapkan rohani mental pasien dan bekerja dengan keterampilan khusus dalam merawat pasien serta harus menjalin komunikasi dengan pasien dan lain-lain.

Menurut Cox yang mengutip laporan studi yang dilakukan oleh Dewe terhadap 1800 perawat 29 rumah sakit di Selandia Baru, mengidentifikasi lima sumber stres kerja, yaitu : beban kerja, kesulitan berhubungan dengan staf lain, kesulitan menjadi perawat di unit perawatan kritis, ketentuan pengobatan pasien, dan kesulitan menghadapi pasien yang tidak ada harapan. ${ }^{10}$

Kondisi perawat puskesmas dengan beban kerja yang tinggi dapat menurunkan pencapaian target pelaksanaan program perawatan kesehatan masyarakat dan 
menurunkan kualitas pelayanan kesehatan di pelayanan rawat jalan maupun rawat inap. Diperlukan upaya untuk menurunkan beban kerja perawat.

Ada beberapa hal yang perlu diperhatikan untuk mengurangi beban kerja perawat yaitu dengan mengevaluasi kembali ketika terjadi peningkatan beban kerja seperti adanya penurunan motivasi kerja, penurunan prestasi kerja seperti staf yang sering tidak masuk kerja, teman kerja yang sering datang terlambat, sehingga penyelesaian kerja menjadi terhambat. Hal ini dapat diatasi dengan sistem pemberian reward dan punishman, peningkatan kompetensi tenaga kerja dan meningkatkan peran pimpinan ${ }^{6}$ Ada beberapa hal yang perlu diperhatikan untuk mengurangi beban kerja perawat yaitu dengan mengevaluasi kembali ketika terjadi peningkatan beban kerja seperti adanya penurunan motivasi kerja, penurunan prestasi kerja seperti staf yang sering tidak masuk kerja, teman kerja yang sering datang terlambat, sehingga penyelesaian kerja menjadi terhambat. Hal ini dapat diatasi dengan sistem pemberian reward dan punishman, peningkatan kompetensi tenaga kerja dan meningkatkan peran pimpinan. ${ }^{8}$

Kepemimpinan merupakan suatu proses pengarahan dan pemberian pengaruh pada kegiatan-kegiatan yang berhubungan tugasnya. Tujuan dan efektifitas suatu organisasi akan tercapai apabila kepemimpinan yang ada berjalan dengan baik.

Peran pemimpin dalam manajemen sebuah institusi termasuk didalamnya peran dalam menanamkan nilai-nilai, norma, etika ke dalam perilaku kerja juga sangat berpengaruh pada setiap bawahan. Saat ini yang banyak berkembang adalah gaya kepemimpinan transaksional, yang dicirikan dengan kepemimpinan yang memotivasi bawahan atau pengikut dengan minat-minat pribadinya, melibatkan nilai-nilai relevan yang sebatas proses pertukaran tetapi tidak langsung menyentuh substansi perubahan yang dikehendaki. Namun gaya kepemimpinan ini nampaknya sudah tidak sesuai, dalam pelayanan kesehatan diperlukan perubahan gaya kepemimpinan agar pelayanan kesehatan berjalan optimal. ${ }^{6}$

Menginspirasi dan mendorong angggotanyauntuk menggunakan metode baru dalam mencari solusi merupakan salah satu kemampuan pemimpin transformasional. ${ }^{11}$ Kepemimpinan transformasional pada dasarnya memiliki empat karakteristik, yang pada akhirnya mampu membuat bawahan lebih mudah menyelesaikan pekerjaan yaitu pengaruh ideal/ kharisma, motivasi inspirasional, stimulasi intelektual, dan perhatian individual. ${ }^{12}$

Pemimpin dalam keperawatan diharapkan dapat menggerakkan sistem dari satu titik ke titik lainnya dalam upaya pemecahan masalah. Maka secara konstan pemimpin harus mengembangkan strategi untuk merubah orang lain dan memecahkan permasalahan yang terjadi pada organisasi yang dipimpinnya. Kepemimpinan transformasional adalah suatu kepemimpinan di mana pemimpin memotivasi bawahannya untuk mengerjakan lebih dari yang diharapkan semula dengan meningkatkan rasa pentingnya bawahan dan nilai pentingnya pekerjaan. ${ }^{13}$

Dibutuhkan sebuah perubahan manajemendan gaya kepemimpinan sehingga perawat dengan beban kerja yang cukup tinggi tetap mampu menyelesaikan perkerjaannya dengan baik dan terhindar dari dampak buruk tingginya beban kerja seperti stress dan penurunan kualitas pelaksanaan perawatan kesehatan masyarakat yang pada akhirnya akan menghambat pencapaian tujuan pembangunan kesehatan nasional yaitu menciptakan derajat kesehatan optimal. Pemimpin keperawatan dalam upaya menurunkan beban kerja perlu menerapkan transformasional leadership sebagai salah satu upaya menurunkan bebab kerja.

\section{Metode}

Metode penulisan Literature review dengan mencari beberapa artikel jurnal penelitian yang dipublikasikan melalui data base eletronik. Data base eletronik yang digunakan: PubMed, EBSCO dan Cochrane Library. Dengan menggunakan kata kunci: transformasi leadership, beban kerja dan perawat puskesmas. Serta menggunakan handbook nursing.

\section{Hasil}

Beban kerja yang berlebihan dan ketidakmampuan tim mengkoordinir tugas 
akan menimbulkan konflik antar anggota tim perawat. Bila setiap perawat tidak mampu mengontrol emosinya akan meningkatkan konflik yang berakibat terhadap teganggunya pelayanan keperawatan yang diberikan. Beragamnya jenis pekerjaan yang harus dilakukan oleh perawat bila tidak ada kerja sama yang baik akan menjadi beban psikis bagi perawat untuk itu perlu adanya tanggung jawab dari tim perawat yang bekerja. Perlu juga adanya kecocokan diantara sesama tim perawat guna mengurangi ketegangan dan perbedaan prinsip satu dengan yang lainnya. Sangat dibutuhkan peran pemimpin untuk mengatur tim.

\section{Pemimpin transformasional lebih sering memakai strategilegitimasi dan melahirkan tingkat identifikasi dan internalisasiyang lebih tinggi, memiliki kinerja yang lebih baik, danmengembangkan pengikutnya. $^{5}$}

Kepemimpinan transformasional yang diterapkan dapat menjadi salah satu jalan menurunkan beban kerja perawat. Pengaruh ideal (idealized influence). Pemimpin transformasional memberikan contoh positif dalam sikap dan perilaku, bagi bawahannya. ${ }^{14}$ Pemimpin memperhatikan bawahannya, memberi visi, serta menanamkan rasa bangga pada bawahannya. Melalui pengaruh seperti ini, para bawahan akan menaruh rasa hormat dan percaya pada pemimpinnya, sehingga mereka berkeinginan untuk melakukan hal yang sama sebagaimana dilakukan sang pemimpin. Seorang perawat yang memegang program kerja lebih dari satu akan melihat pemimpin yang telah memberikan contoh bekrja optimal sehingga dapat meningkatkan semangat kerja dan tidak merasakan pekerjaan sebagai suatu beban, pemimpin juga memberikan suatu bekal untuk selalu mengkutsertakan pemegang program yang baru dalam suatu pelatihan dan meminta bimbingan teknis dari dinas kesehatan agar mudah melaksanakan program sehingga beban kerja yang tinggi dapat diturunkan.

Motivasi Inspirasional (inspirational motivation). Motivasi inspirasional merupakan kemampuan dalam mengkomunikasikan harapan dan mengekspresikan tujuan dengan cara-cara yang sederhana. $^{8}$ Pemimpin transformasional dapat menstimulasi antusiasme bawahannya untuk bekerja dalam kelompok dan mengembangkan keyakinan bawahan untuk mencapai tujuan bersama serta membangkitkan semangat kerja secara inspirasional, yaitu mendorong karyawan untuk meningkatkan kinerja melebihi dugaan mereka sendiri. ${ }^{15}$

Menurut Robbins (2010) bahwa pemimpin transformasional menginspirasi para pengikut untuk mengenyampingkan kepentinganpribadi mereka demi kebaikan organisasi dan pemimpin transformasional mampu memiliki pengaruh yang luar biasa pada diripara pengikut. Mengubah kesadaran para pengikut dengan caramembantu orang lain memandang masalah lama dengan cara yang barudan dapat mengsinspirasikan para pengikut untuk bekerja keras gunamencapai tujuan bersama.

Dengan antusiasme yang tinggi dalam bekerja, perawat dapat melakukan pekerjaan yang lebih tinggi, bahkan untuk ikut serta dalam menyelesaikan tugas-tugas administrasi. Adanya keyakinan untuk mencapai tujan bersama akanmenjadikan suatu target program yang tingi mudah dicapai oleh pengelola program sekaligus mampu tetap melaksanakan kegiatan rawat jalan di dalam puskesmas. Dengan demikian beban kerja secara psikologis dapat dikurangi.

Dalam hal motivasi inspirasional, pemimpin transformasionalmenyampaikan visi yang jelas, membangun mimpi dan komitmen danmembantu pengikut untuk memahami tujuan, sasaran dan prioritas dari organisasi, sehingga bawahan sangat antusias dengan visi yang digapai.Keberhasilan dari sebuah visi bergantung pada cara menyampaikankepada pengikut.

Stimulasi intelektual (intellectual stimulation). Pemimpin transformasional berupaya menciptakan iklim yang kondusif bagi pengembangan ide. ${ }^{14} \mathrm{Hal}$ ini diperlukan untuk menemukan stragegi pencapaian target program yang seringkali lebih tinggi daripada perkiraan di lapangan. Untuk itu bawahan benar-benar dilibatkan dalam proses perumusan masalah dan pencarian solusi saat ada hambatan dalam pelaksanaan program maupun dalam pencapaian target program. 
Seringkali iklim yang kondusif mampu menyebabkanhilangnya ketidakmampuan mengembangkan ide untuk menemukan cara dan strategi pencapaian program.

Hal lain dapat dilakukan untuk mencapai target program dan meningkatkan kinerja sehingga tugas dapat terselaikandengan baik adalah dengan memfasilitasi pelatihanpelatihan.. Dalam sebuah pelatihan, sering terdapat sharing pendapat dari pencapaian target program yang tinggi,bagaimana cara dan strategi serta upaya yang pernah dilakukan untuk mencapai target program tersebut.

Dalam stimulasi intelektual, pemimpin transformasional meningkatkan kesadaran pengikut akan permasalahan danmempengaruhi para pengikut untuk memandang masalah dari perspektif yang baru.

Dalam sebuah organisasi sering terjadi perbedaan dalam upayamelakukan dan melaksanakan sebuah program atau kegiatan. Perbedaan pendapat dipandang sebagai hal yang biasa terjadi. Hal tersebut akan membuat efikasi diri bawahan semakin kuat, sehingga para bawahan akan sanggup mengerjakan dan berhasil dalam melakukan berbagai tugas yang menantang dan lebih dari apa yang seharusnya dapat mereka kerjakan.

Perhatian individual (individualized consideration). Pemimpin transformasional memberikan perhatian pada bawahannya secara personal, menghargai perbedaan setiap individu, memberi nasehat serta penghargaan. ${ }^{14}$ Perhatian secara personal merupakan identifikasi awal terhadap potensi para bawahan, kelebihan dan kekurangan bawahan diketahui dengan tepat dan bawahan ditempatkan serta diberi beban sesuai potensinya. Misalnya, ada seseorang yang komunikasinya baik namun kurang ulet dalam melaksanakan hal yang rinci, maka orang tersebut diberi banyak beban untuk mengkomunikasikan suatu program kepada kelompok masyarakatyang sulit mengikuti program. Ada juga tipe yang mampu dengan baik dan teliti dalam penyusunan program dan lebih mampu menganalisa, maka orang tersebut harus mendapatkan tempat yang tepat, misalnya dalam perencaan dan pelaporan.
Sedangkan monitoring dan pengarahan merupakan bentuk perhatian secara personal yang diaplikasikan melalui tindakan konsultasi, nasehat dan tuntunan yang diberikan oleh pemimpin transformasional. Pemimpin harus selalu melakukan tindakan kontroling sehingga mengetahui setiap ada permasalahan sekecil apapun dan segera memberikan perhatian, bimbingan dan arahan untuk mengatasi masalah tersebut. Dengan perhatian yang sungguh-sungguh diberikan, setiap bawahan akan merasakan peran pemimpin tersebut dan menjadikan pemimpin sebagai tempat konsultasi, bukan sekedar tempat untuk melaporkan hasil kegiatan tanpa mengetahui masalah yang terjadi selama bawahan melakukan suatu tindakan.

\section{Pembahasan}

Carr-Hill dan Jenkins-Clarke (1995) menyatakan bahwa kepemimpinan sangat berpengaruh pada kualitas pelayanan, lingkungan dan beban kerja, kepemimpinan transformasional mampu membuat kualitas pelayanan kesehatan meningkat seiring membaiknya lingkungan kerja dan beban kerja yang menurun karena bawah merasakan ia adalah bagian penting dalam pekerjaannya. ${ }^{16}$

Gaya kepemimpinan transformasional berpengaruh secara signifikan dan positif terkait dengan kualitas asuhan dan semua pekerjaan psikososial variabel lingkungan, dan beban kerja. ${ }^{17}$

Efek psikologis yang paling sederhana dan jelas dari kelebihan beban kerja adalah stress kerja yang mengakibatkan menurunnya motivasi kerja perawat dalam memberikan asuhan keperawatan. Motivasi sangat dibutuhkan oleh seorang perawat sebagai dorongan untuk meningkatkan gairah kerja. Kinerja perawat timbul sebagai respon efektif atau emosional terhadap tugas pekerjaan yang dilakukan perawat. Stress kerja disebabkan oleh konflik kerja, beban kerja, waktu kerja, karakteristik tugas, dukungan kelompok dan pengaruh kepemimpinan (Rusman, 2006).

Hasil studi Burn tentang kepemimpinan dari waktu ke waktu, menunjukan bahwa pemimpin yang paling 
sukses untuk melakukan perubahan adalah mereka yang telah berusaha menerapkan kepemimpinan transformatif atau transformasional. ${ }^{18}$

Pemimpin perlu membangkitkan antusiasme bawahannya agar karyawan merasa pemimpinnya memberikan motivasi dalam melaksanakan pekerjaan, dan pemimpin dapat menjalin kerjasama yang baik dengan karyawannya. Sehingga mampu membangkitkan kepuasan kerja karyawan. ${ }^{18}$ Pemimpin mempunyai kewajiban memberikan perhatian yang sungguh-sungguhuntuk membina, menggerakkan, mengarahkansemua potensi anggota di lingkungannya untukmencapai tujuan organisasi. ${ }^{11}$

Bekerja pada unit tertentu berpengaruh terhadap kinerja. ${ }^{11}$ Awases etal. (2013) menyatakan bahwa perawat dengan beban kerja yang lebih besar dari staf yang tersedia berdampak pada peningkatan ketidakhadiran dan penurunan kualitas kerjaatau kinerja perawat. Namun kemungkinan kasus keperawatan di unit rawat inap yang lebihb ervariasi dibandingkan unit lain menuntut mereka kreatif dan inovatif dalam bekerjasesuai dengan kondisi ruangan, serta tuntutantugas secara kuantitatif, fisik, emosional (Al-Homayan et al., 2013). Daya kreativitas ini dapat muncul karena motivasi pemimpin dengan menyediakan lingkungan kerja yang baik. Pendapat ini didukung oleh Suryanto et al.(2011) bahwa pemimpin berpengaruh meningkatkan daya kreativitas anggotanya. ${ }^{16}$

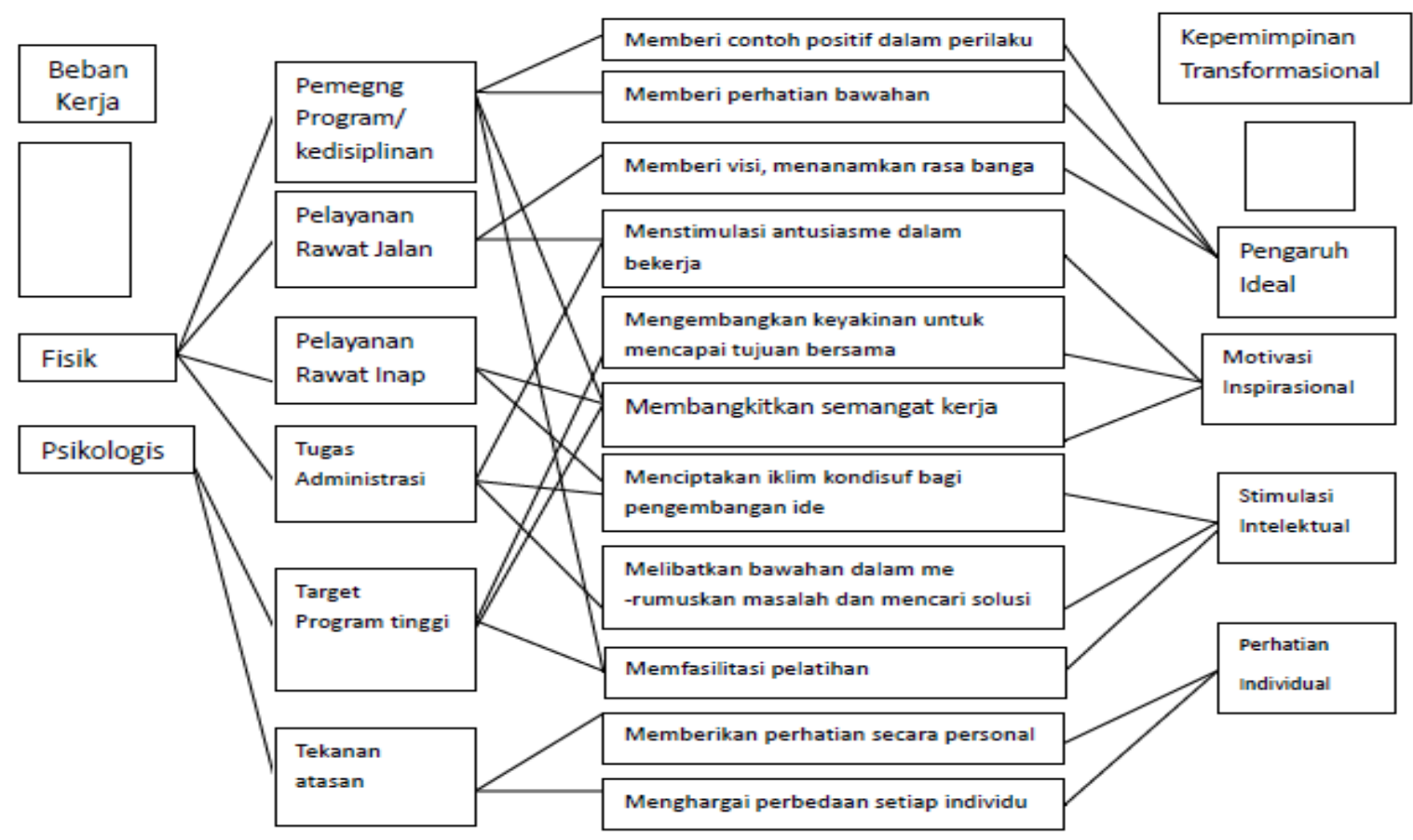

Bagan 1. Transformasional Leadeship menurunkan beban perawat

Pemimpin akan mampu membuat bawahannya menyadari perspektif yang lebih luas, sehingga kepentingan individu akan disubordinasikan terhadap kepentingan kelompok, institusi, atau kepentingan lain yang lebih luas. ${ }^{19}$
Pemimpin transformasional bisa mengkomunikasikan visi mereka dengan cara yang membuat orang merasa begitu berarti dan mengasyikkan bahwa hal itu mengurangi negativitas dan menginspirasi komitmen pada orang-orang dengan siapa mereka bekerja. Jika berhasil, tujuannya pemimpin dan staf akan menjadi menyatu, menciptakan kesatuan, keutuhan, tercapai tujuan bersama dan tidak 
merasakan beberapa pekerjaan sebagai suatu beban kerja.

Mengarahkan, menggerakkan dan memotivasi staf perawat bekerja dengan sebaik-baiknya adalah salah satu fungsi dari pimpinan/ perawat manajer. Sering dijumpai seorang perawat melaksanakan tugas tidak sesuai dengan tuntutan dan kebutuhan. Hal ini semata mata bukan kesalahan atau kekeliruan perawat tetapi sering juga disebabkan oleh kurangnya pengarahan dari ppimpinan sebelum tugas dilaksanakan. Pengarahan yang kurang tepat dapat menimbulkan beban psikis bagi perawat dalam melaksanakan tugasnya. Beban psikis semakin berat bila perawat mengalami kelebihan beban kerja dan penempatan tenaga kerja yang dilakukan oleh pimpinan tidak sesuai dengan kebutuhan tenaga keperawatan. Kelebihan beban kerja dapat terjadi karena harapan pimpinan terhadap pelayanan yang berkualitas, sedangkan pengetahuan dan ketrampilan yang dimiliki perawat tidak sebanding sehingga bisa menjadi beban psikis bagi perawat bersangkutan. Hal lainnya bisa karena adanya tanggung jawab yang tinggi dalam melaksanakan asuhan klien. Menurut Rusman (2006), pengaruh kepemimpinan bisa menyebabkan timbulnya stress kerja akibat beban kerja berlebihan yang dilimpahkan oleh pimpinan.

Untuk menciptakan hubungan yang harmonis antara perawat dengan pimpinan, maka pimpinan harus memiliki kemampuan seperti memberikan pengarahan dan petunjuk yang jelas, sehingga dapat dimengerti oleh pelaksana keperawatan, memberikan saran/nasehat dan bantuan kepada pelaksana keperawatan, memberikan motivasi untuk meningkatkan semangat kerja pelaksana keperawatan, memberikan latihan dan bimbingan yang diperlukan serta memberikan penghargaan bagi yang berprestasi dan hukuman bagi yang melanggar peraturan. Selain dari pimpinan, perawat juga diharapkan dapat melaksanakan arahan yang diberikan oleh pimpinan dan melaksanakan tanggung jawab yang diberikan dengan sebaik-baiknya.

Gaya kepemimpinan transformasional dan pengembangan SDM merupakan suatu hal yang tidak dapat diabaikan untuk memaksimalkan kinerja perawat. ${ }^{20}$ Penelitian menunjukkan adanya pimpinan yang menginspirasi bawahan dan emotivasi akan meningkatkan kinerja perawat. Sebagaian perawat mengakui pimpinan belum memberikan sugesti postitif untuk meningkatkan motivasi. ${ }^{21}$

Pemimpin memberikan penilaian berdasarkan proses proses selama bekerja (Awases, Bezuidenhout, \& Roos, 2013), mendorong karyawan untuk mencapai hasil yang lebih tinggi (Northouse, 2009), memperhitungkan emosi karyawan, nilai-nilai, etnis, standar dan tujuan jangka panjang (Ahmad et al., 2013) yang dapat digunakan untuk mempengaruhi karyawan atau bahkan seluruh organisasi dengan melibatkan agen sosialisasi. ${ }^{8}$

Awases et al. (2013) menyatakan bahwa perawat dengan beban kerja yang lebih besar dari staf yang tersedia berdampak pada peningkatan ketidakhadiran dan penurunan kualitas kerja, namun kemungkinan kasus keperawatan yang lebih bervariasi menuntut mereka kreatif dan inovatif dalam bekerja serta tuntutan tugas secara kuantitatif, fisik, emosional (Al-Homayan et al., 2013). Daya kreativitas ini dapat muncul karena motivasi pemimpin transformasional dengan menyediakan lingkungan kerja yang baik. Pendapat ini didukung oleh Suryanto et al. (2011) bahwa pemimpin berpengaruh meningkatkan daya kreativitas anggotanya. ${ }^{11}$

Kepemimpinan transformasional yang saat ini baru mulai diterapkan oleh beberapa manajer di beberapa institusi merupakan suatu upaya yang dilakukan oleh seorang pemimpin untuk membuat bawahan merasa lebih nyaman dalam bekerja, stimulasi intelektual yag diberikan mampu meningkatkan kompetensi perawat sehingga mengurangi stres dan membuat perawat lebih mudah menyelesaikan pekerjaan yang diberikan kepadanya dan merasakan bahwa tugas dan beban kerja yang diberikan kepadanya tidak tinggi.

\section{Kesimpulan}

Dari berbagai jurnal yang telah direview dapat diambil kesimpulan bahwa transformasional leadership berpengaruh positif untuk menurunkan beban kerja perawat di puskesmas. Empat pola kepemimpinan transformasional yaitu pengaruh ideal 
(idealized influence), motivasi inspirasional (inspirational motivation), stimulasi intelektual (intellectual stimulation) dan perhatian individual (individualized consideration) mampu menjadikan beban kerja yang tinggi dirasakan menurun.

\section{Saran}

Untuk mengoptimalkan kinerja perawat dan menjadikan beban kerja tidak dirasakan berat oleh perawat, kepemimpinan transformasional perlu diterapkan pada level manajemen di institusi pelayanan kesehatan sehingga perawat terhindar dari stress akibat beban kerja yang tinggi dan pelayanan kesehatan lebih optimal.

\section{DAFTAR PUSTAKA}

1. RI K. Pedoman Penyelenggaraan Upaya Keperawatan Kesehatan Masyarakat di Puskesmas. 2006.

2. Silano YV, Kapantow N, Josephus J. Hubungan Antara Beban Kerja dengan Kinerja Tenaga Kesehatan. 2014;1-7.

3. Laraswatie $\mathrm{H}$, Tjahjono $\mathrm{K}$, Jati SP. Kebutuhan Perawat Puskesmas Berbasis Analisis Beban Kerja ( Studi Kasus Di Puskesmas Rembang 2 Kabupaten Rembang ) A Nurse' s Necessity at Health Centre based on Workload Analysis ( Case Study at Puskesmas Rembang 2 Kabupaten Rembang ). 2016;4(2):118-22.

4. Acar M, Robertson PJ. Accountability Challenges in Networks and Partnerships: Evidence from Educational Partnerships in the United States. Int Rev Adm Sci. 2004;70(June 2002):331-44.

5. Nursalam. Manajemen Keperawatan. 4th ed. Jakarta: Salemba Medika; 2014.

6. Sato P masa, Kadir A. Hubungan Beban Kerja dengan Jumlah Perawat di Puskesmas Waepana Kecamatan SOA Kabupaten Ngada Propinsi NTT Tahun 2013. 2014;5:379-84.

7. Hamidullah B, Sait D. Role of Transformational Leadership on Employee's Job Satisfaction: the Case of Private Universities in Bosnia and Herzegovina. 2015;(93):270-82.

8. Westerberg K, Tafvelin S. The importance of leadership style and psychosocial work environment to staff-assessed quality of care: implications for home help services.
2014;22:461-8.

9. Care H. Transformational Leadership in Health Care. 2014;26.

10. Kasmarani MK. Pengaruh Beban Kerja Fisik dan Mental terhadap stres kerja pada perawat di Instalasi Gawat Darurat (IGD) RSUD Cianjur. J Kesehat Masy. 2012;2.

11. Wijayanti. Gaya Kepemimpinan Transaksional Meningkatkan Kinerja Perawat Pelaksana. 2016;(2013):205-12.

12. Kelly P. Essentials of Nursing Leadership and Management. second. USA: Delmar; 2010 .

13. Whitebead DK, Weiss SA, Tappen R. Essentials of Nursing Leadership and Management. fifth. Philadelphia: F.A. Davis Company; 2010.

14. Bass BM, Riggio RE. Transformational Leadership. second. London: Lawrence Erlbaum Associates; 2006.

15. Herman S, Gish M, Rosenblum R, Herman M. Effects of RN Age and Experience on Transformational Leadership Practices. JONA J Nurs Adm [Internet]. 2017;47(6):327-37. Available from: http://insights.ovid.com/crossref?an=00005 110-201706000-00007

16. Vázquez-Calatayud M, Oroviogoicoechea C, Saracibar M, Pumar-Méndez MJ. Transforming care in nursing: a concept analysis. Contemp Nurse. 2017;53(2):21734.

17. Jun SY. The Mediating Effect of Social Capital on the Relationship Between Public Health Managers' Transformational Leadership and Public Health Nurses' Organizational Empowerment in Korea Public Health. Asian Nurs Res (Korean Soc Nurs Sci) [Internet]. 2017; Available from: http://dx.doi.org/10.1016/j.anr.2017.08.006

18. Afandi R. Efektifitas Kepemimpinan Transformasional Pesantren Bagi Peningkatan Mutu Lembaga Pendidikan Islam. 2013;1(1):99-122.

19. Asamani JA, Naab F, Maria A, Ofei A. Leadership styles in nursing management: implications for staff outcomes. 2016;6(1):23-36.

20. Olu-abiodun O, Abiodun O. International Journal of Africa Nursing Sciences Perception of transformational leadership behaviour among general hospital nurses in Ogun State , Nigeria. Int J Africa Nurs Sci [Internet]. 2017;6:22-7. Available from: http://dx.doi.org/10.1016/j.ijans.2017.02.00 1

21. Doody O, Doody CM. Transformational Leadership in nursing practice. 2012;21(20). 